\title{
Legalization and Islamic Bioethical Perspectives on Prenatal Diagnosis and Advanced Uses of Preimplantation Genetic Diagnosis in Saudi Arabia
}

Hanan A. Sultan ${ }^{1 *}$ and Joyce C. Harper ${ }^{1,2}$

${ }^{1}$ Consultant Obstetricians and Gynaecologist- MOH Jeddah, Saudi Arabia, Reproductive Medicine and Surgery Specialist, PhD researcher at UCL centre for Preimplantation Genetics and Diagnosis - London UK

${ }^{2}$ University College London Centre for Pre-implantation Genetics and Diagnosis, Elizabeth Garrett Anderson Institute for Women's Health, University College London, London, United Kingdom. Centre for Reproductive and Genetic Health, Elizabeth Garrett Anderson Institute for Women's Health, University College London Hospital,

London, United Kingdom

Pre-implantation genetic diagnosis (PGD) was introduced more than 20 years ago [1]. This technique was available to fertile couples to overcome genetic problems, chromosomal abnormalities and inherited single-gene disorders and to select gender for both medical and non-medical reasons. More recently, PGD has been extended to screening for late onset diseases, cancer predisposition [2,3] and HLA matching to disease-affected siblings to provide a source for stem cell transplantation [4-7]. The practice of PGD remains a worldwide subject of debate. In the last two decades, the influence of religion on bioethics has declined, and the subject has become dominated by secular philosophical, social, and legal concepts. However, in the Middle East, religion still significantly influences social behaviors, attitudes, practices and policy-making [8].

\section{Islamic Law and Fatwa}

Islamic Shari'a law is the set of instructions that regulate everyday life and that must be followed by observant Muslims. Shari'a is flexible enough to adapt to emerging situations in different times and places. It is regulated by the following authorities, in chronological and hierarchal order: 1) The Quran, which Muslims believe to be the very word of God; 2) The Sunna (traditions) and Hadith (statements), which are the authentic traditions and sayings of the Prophet Mohamed, as collected by specialists in Hadith; 3) Igmaah, which is the unanimous opinion of Islamic scholars; 4) Analogy (Kias), which is the intelligent reasoning used to rule on events not mentioned by the Quran and Sunna, based on precedents set by similar or equivalent events; and 5) Fatwa (consensus edict), a formal legal opinion or interpretation given by a jurisconsult ( $m u f t i$ in response to a request from a judge (qadi) or an individual.

The fatwa is generally produced privately by a mufti or by an organization appointed by the government or state, such as The Saudi Council of Senior Scholars (CSS), the Islamic Fiqh Academy (IFA) in Jeddah, the Islamic Organization for Medical Sciences in Kuwait, Dar El-Iftaa (Al-Azhar) in Cairo, or the Islamic Fiqh Academy India (IFAI). These fatawa are not binding by law; they remain discretionary and may change with changes in evidence. In cases where there are different opinions or fatawa, the final decision is left to the legal authority. Every Islamic country has its own legislation.

\section{Legal Authority in Saudi Arabia}

The government in the Kingdom of Saudi Arabia is based on justice, Shoura (consultation) and equality, according to Islamic Shari'a [9]. The Consultative Assembly of Saudi Arabia, or the Shoura Council, is the country's legislature. Since its establishment in 1926 by King Abdul-Aziz, the Shoura Council has debated and discussed issues related to the state and its citizens to fulfill the divine order by applying Shari'a (Islamic Jurisprudence) and Shoura. Currently in its $5^{\text {th }}$ term, the council has achieved a place in the International Parliamentary
Union. It has 150 male members, each appointed by royal decree. The Shoura council passes its recommendations to the council of Ministers, which is the cabinet of Saudi Arabia; this council is led by the King, who is also the Prime Minister. In September 2011, a new law was introduced by King Abdullah Bin Abdulaziz allowing women to run in municipal elections and to become members of the Shoura council for the first time. This new law will take effect by 2015 .

The legal fatwa in Saudi Arabia are issued through the General Presidency of Scholarly Research and Fatwa (GPSRF). This organization was established by a royal decree on August 29, 1971 to prepare research papers for discussion among the CSS and to issue fatwa on individual issues by responding to the fatwa-seeking public in the areas of doctrine, worship and social issues through a permanent committee. The GPSRF has 17 members appointed by royal decree.

The IFA is a subsidiary of the Organization of the Islamic Conference (OIC), created by the third Islamic summit conference held in Makkah Al-Mukarama, Saudi Arabia in January 1981. It is based in Jeddah, Saudi Arabia. Its members and experts are selected from among the best scholars and thinkers in the Islamic world (57 Islamic countries) and Muslims in non-Muslim countries in every field of knowledge (e.g., Islamic Fiqh, science, medicine, economics and culture). The consensus groups include a diverse representation of scholars. Specialists, such as clinicians and scientists, are called upon to provide the background information necessary to make appropriate decisions. In August 2010, a royal decree confirmed the role of the CSS as the main legal organization responsible for issuing fatwa in Saudi Arabia.

\section{Legalization of reproductive technology in Saudi Arabia}

In vitro fertilization (IVF) was introduced to Saudi Arabia in the 1980s by private clinics. Currently, there are thirty IVF units in the

*Corresponding author: Dr. Hanan A. Sultan, MBChB, DGO, MRCOG, ABOG, FRCOG, MSc, Consultant Obstetricians and Gynaecologist- $\mathrm{MOH}$ Jeddah, Saudi Arabia, Reproductive Medicine and Surgery Specialist, $\mathrm{PhD}$ researcher at UCL centre for Preimplantation Genetics and Diagnosis - London UK, Tel : 00447714259001/00966505616617; Fax: 00442087436344/ 0096626609927; E-mail: haaa.sultan@yahoo.co.uk

Received November 01, 2011; Accepted February 27, 2012; Published March 05, 2012

Citation: Sultan HA, Harper JC (2012) Legalization and Islamic Bioethical Perspectives on Prenatal Diagnosis and Advanced Uses of Preimplantation Genetic Diagnosis in Saudi Arabia. J Clinic Res Bioeth S1:003. doi:10.4172/21559627.S1-003

Copyright: ( 2012 Sultan HA, et al. This is an open-access article distributed under the terms of the Creative Commons Attribution License, which permits unrestricted use, distribution, and reproduction in any medium, provided the original author and source are credited. 
country. Nine are governmental, and twenty-one are private. The regulation of these centers is governed by the Ministry of Health $(\mathrm{MOH})$, the health authority in Saudi, which establishes guidelines. However, the implementation of these guidelines is left to the discretion of the individual units [10].

In January 2006, the Saudi Minister of Health issued the first code of practice to regulate all ART through a ministerial decree based on royal decree and Shoura council recommendations. The regulatory code has six chapters (general provisions; oversight committee; license terms for the IVF units; committee to consider violations; sanctions; and final provisions). The code indicates that all IVF units in Saudi should follow the fatwa from the Saudi CSS and that all staff should be aware of and possess a copy of these fatwa [11]. Embryo freezing is allowed as long as precautions are taken to avoid any mixing-up of the embryos [12], although the IFA fatwa of 1990 prohibits any gamete or embryo freezing. Embryo or gamete research is also allowed with the agreement of the couple and the oversight committee [13]. An annual report of all treated cases is to be sent to the oversight committee, including the relevant patient identification numbers [14]

The oversight committee (not yet formed) was approved by resolution of the Minister of Health [15]. The Committee will be chaired by the undersecretary of the Minister of Health. Committee members will include highly experienced specialists in the fields of IVF and law who are appointed by the Ministers of Health, Justice, and High Education. All members have three-year tenures. The main duties of this committee will be to license all IVF units in Saudi Arabia and to ensure that they follow the IVF code of practice, to consider requests for IVF research and medical experiments, to form a technical committee to ensure that the license terms are satisfied, and to inspect and follow up all IVF units.

A committee to examine violations of the provisions of the rules will also be established [16]. This committee will be chaired by a level-A judge elected by the Minister of Justice. Members will include highly experienced specialists in obstetrics and gynecology, IVF, and neonatology as well as a legal adviser.

\section{Islamic and Medical Bioethics}

Islamic bioethics emphasizes prevention, particularly the obligation to preserve life and seek treatment. It teaches that patients must be treated with respect and compassion and that the physical, mental and spiritual dimensions of illness should be taken in to account [17]. Islamic bioethics is based on principles, duties, rights and obligations (to preserve life and seek treatment) with respect to patient autonomy [17] and, to a certain extent, a call to virtue (Ihsan). Bioethics decision making is conducted within the framework of values derived from revelation and tradition [17].

Five Shari'a principles govern medical bioethics: 1) the protection of human life (saving one life represents saving the lives of all mankind); 2) physical well-being takes precedence over religious well-being; 3 ) necessities override prohibitions; 4) preventing harm is preferable to procuring benefits (the basic concept in harmful matters is prohibition, whereas the basic concept in useful matters is permissiveness); and 5) maslaha, or the public good, requires help and care for the ill and needy [18-20].

The western medical ethics of autonomy (respect for the freedom of choice of a competent individual and protection of incompetent persons), non-maleficence (do no harm), beneficence (promoting the well-being of others), and justice (promoting a fair allocation and distribution of health costs and benefits as well as fair compensation for errors or shortcomings by individuals or groups) are similar to the Islamic principles, with some differences in duties and obligations. For example, the principle of autonomy in Islamic bioethics emphasizes the value of man as a vicegerent of God on earth, the idea that human bodies belong to God and that each individual is fully responsible for ensuring that his body is not intentionally harmed, and the importance of public benefits (maslaha) and prioritizing, in which the collective interest takes precedence over the interests of the individual and the family as the decisive unit for any personal decision [21]. The Islamic concept of justice considers fairness rather than equality and seeks to consider the interests and needs of individuals appropriately. In this context, justice in medical ethics refers to treating persons and groups equitably and distributing the benefits and burdens of health care as fairly as possible in society $[22,23]$.

\section{Infertility Treatment in Islam}

Because Islam encourages marriage, the formation of family units, and procreation, the treatment of infertility, including ART, is encouraged in cases of otherwise incurable infertility. A basic concept in Islam is that each child should be related to a known father and mother. Legal adoption is not allowed because it implies that children are deceived about their true genetic heritage, but Islam encourages the fostering of orphans. Surrogacy is not accepted in Islam [24,25] because the Quran states, "None can be their mothers except those who gave them birth".

Several fatawa and guidelines have approved ART as a treatment for infertility, provided that it is used within the framework of a marriage and does not involve a third party or the mixing of genes. These fatawa have been established by Dar El Iftaa, Cairo (1980); IFA, Jeddah (1984 and 1990) (IFA-Jeddah, 2000); the Organization for Medical Sciences in Kuwait (1983); Qatar University (1993); the Islamic Organization for Education, Science and Culture in Rabaat (2002); the United Arab Emirate (2002); and the International Islamic Center for Population Studies and Research (IICPSR) at al-Azhar University $(1984,1997,2000)$.

\section{Consanguinity and Islam}

Consanguinity occurs in at least $20 \%$ of the human population worldwide, and $8.5 \%$ of all children have consanguineous parents [26]. Consanguinity is integral to many societies and has many social and economic benefits [20], such as the preservation of wealth (particularly land), psychosocial advantages, and benefits to geographical and tribal traditions [27]. Between $20-70 \%$ of all marriages in the Arab world were consanguineous before Islam was widely adopted [28-30].

Consanguinity is common in Saudi Arabia, occurring in 30-70\% of all marriages, depending on the province [31-34], and in $67.3 \%$ of families of handicapped children $(40.9 \%$ and $26.4 \%$ in first- and second-cousin marriages, respectively) [35]. These high percentages of consanguinity and the tribal nature of marriage have resulted in a high incidence of genetic disorders [36]. Although one communitybased cross-sectional study was conducted to evaluate the impact of consanguinity on the prevalence of genetic disease in Saudi Arabia, it did not show a significant correlation, with the exception of congenital heart disease [37,38]. Islamic teachings neither encourage nor discourage consanguinity; the matter is left to individual choice. However, Islam encourages the prevention of disease and the promotion of healthy families.

In some provinces of Saudi Arabia, intermarriage between carriers 
of autosomal recessive disorders is high [39]. This phenomenon has led to a high prevalence of these diseases in some provinces, as much as $20-25 \%$ in the Eastern [40,41], Madina and South provinces [40,42,43]. These diseases pose a challenge to the health authorities in the country.

Informed premarital screening for genetic blood disorders was advocated in 2004, after approval by the CSS [41], as a strategy to identify high-risk couples and provide counseling [44]. Preliminary data showed that the groups at the greatest risk for genetic disorders do not take advantage of the opportunity for premarital screening [45], even though termination is prohibited for this condition. Furthermore, $98 \%$ of the counseled couples proceeded with the marriages, producing 15 children with genetic diseases over 4 years [46]. These data support the need for PGD as the only realistic measure for the prevention of genetic diseases in Saudi Arabia.

\section{The Moral Status of the Embryo in Islam}

Islamic teachings from the Quran do not provide exact periods for the different stages of embryo development. The sayings of the Prophet Mohamed refer to three 40-day stages: the Nutfa, referring to mixed drops of male and female sexual discharge (sperm and egg), followed by the alagha, or clot, and the Mudgha, or fleshy lump. The embryo becomes "another creation" after ensoulment. Scholars conclude that fetal ensoulment occurs at the time of "another creation", but they disagree as to whether ensoulment occurs after the first or third 40 days (40 or 120 days), according to their understanding of the Hadith. Accordingly, some scholars believe that ensoulment occurs at 120 days from conception (classic jurists) and allow the termination of pregnancy (TOP) before 120 days for fetal indications, such as severe untreatable fetal congenital abnormalities that may cause subsequent pain to the baby or his family after birth [47-49]. In contrast, other scholars, especially in the Maliki and Hanbili Schools, believe that ensoulment follows the first 40 days; thus, they allow TOP for fetal indications only before 40 days [50,51]. Prior to 40 days, the embryo has sanctity, but is not comparable to that of a full human being; thus, embryo research is allowed before 40 days. The main differences between these two groups of scholars arise from differences in their understanding of the Prophet's Hadith [52,53]. However, all scholars agree that TOP is allowed in Islam at any time following conception if the mother's life is in danger because the life of the mother is valued more highly than that of the fetus $[50,52,53]$. The sanctity of the embryo/fetus considers the development of human life to begin at implantation. The fetus has a right to live and is accorded respect according to all schools of Islamic law.

\section{Islamic Bioethics and PND/PGD}

PND employs a variety of techniques that can be applied to a pregnant woman to determine the health and condition of an unborn fetus, and TOP can subsequently be performed if the couple chooses. PGD combines IVF and genetic diagnosis to allow the identification of abnormal embryos prior to implantation (pregnancy) [1,54]. Couples who are at risk of having children with serious genetic diseases can select only unaffected embryos for transfer to the uterus, eliminating the need for PND and TOP. PGD involves two stages: embryo biopsy followed by genetic testing through analysis of the DNA from a single cell using polymerase chain reaction (PCR) and/or fluorescence in situ hybridization (FISH). Recently, genetic testing with array technology has been used to screen for greater numbers of abnormalities in embryos [55].

Islam encourages the prevention of disease through PND or PGD because these methods fulfill the following principles of Islamic Shari'a: physical well-being has precedence over religious well-being; the basic concept in useful matters is permissibility; necessities override prohibitions; preventing harm is preferable to procuring benefits; and the basic concept in harmful matters is prohibition [20]. However, PGD is preferable to PND in Islam because the protection of human life is one of the main principles of Shari'a. All of these principles indicate that any procedure that helps to produce a healthy family should be encouraged, as long as it is conducted within the Islamic frameworkbetween a husband and wife with a valid marriage contract.

A workshop organized by IICPSR in Al-Azhar in 2000 recognized the importance of PGD and noted that PGD is encouraged because it helps to prevent diseases. The workshop also concluded that sex selection for family balancing is allowed provided that the couple has three children of the same sex and no children of the desired sex $[56,57]$. At an international seminar held in Cairo in 2007 and organized by the Islamic Organization for Medical Sciences in collaboration with the East Mediterranean Regional Office of WHO (EMRO), UNESCO, the Islamic Science, Education and Culture organization (ISESCO) and the Islamic Fiqh Academy (IFA) Council in Jeddah, it was declared that any embryo that shows serious chromosomal or genetic anomalies, such as aneuploidy, cystic fibrosis, muscular dystrophy or hemophilia, should not be transferred [57]

\section{Sex Selection and Islamic Law}

Sex selection for non-medical indications through PGD continues to be illegal or highly controversial in most countries [58]. It is prohibited in many European countries [59]. Many professionals in the PGD field do not accept sex selection [60], because it raises complicated questions of sexism and gender stereotyping, the allocation of medical resources, respect for the earliest stages of human life [61], and the procreative autonomy and liberty of a couple [62]. There is a fear that the selection of "designer babies" may distort the sex ratio, usually in favor of boys [59].

Infanticide targeting girls was common in the Arab peninsula prior to the spread of Islam, but it is prohibited by the Quran. The Prophet Mohamed encourages the raising of female children in three Hadith: "Whoever takes care of two girls until they reach adulthood - he and I will be (together) on the Day of Resurrection - and he interlaced his fingers (meaning in Paradise)"; "Whoever has three daughters or sisters, or two daughters or two sisters, and lives along with them in a good manner, and has patience with them, and fears God with regard to them will enter Paradise"; and "They will be a shield for him from the Fire".

Sex ratio balancing in Islam is acceptable to satisfy a sense of religious or family obligation and to save women from increasingly risky pregnancies $[57,62,63]$. In principle, sex selection is allowed in Islam through natural, non-medical methods, such as the use of chemicals (herbal remedies) or specific diets [64]. The use of PGD for non-medical reasons, such as to balance the sex ratio in the family, is allowed only in special circumstances by Al-Azhar fatwa $[8,56]$. The IFA recently prohibited social sexing by PGD, declaring that sex selection through PGD should be used only to prevent X-linked diseases and that its use should be approved on a case by-case basis by a specialized committee $[64,65]$, mainly because IVF/PGD carries a risk to the mother. The Inter-Governmental Bioethical Committee (IGBC), held at UNESCO headquarters in Paris in 2003, also prohibited social sexing through PGD [66]. 


\begin{tabular}{|c|c|c|c|}
\hline & $\begin{array}{l}\text { Jeddah centre } \\
\text { Western region }\end{array}$ & $\begin{array}{l}\text { Riyadh centre } \\
\text { Central region }\end{array}$ & $\begin{array}{l}\text { Al-Khubar centre } \\
\text { Eastern region }\end{array}$ \\
\hline Type & $\begin{array}{l}\text { Private headquarters for another two } \\
\text { satellite IVF centres (Riyadh and Al- } \\
\text { Khubar) }\end{array}$ & Government-funded tertiary centre & Private tertiary centre \\
\hline Referral and services offered & $\begin{array}{l}\text { Two satellite centre and four referral } \\
\text { centres for sex selection and PGD in } \\
\text { Riyadh and the south province }\end{array}$ & $\begin{array}{l}\text { Serve the whole country for monogenic } \\
\text { translocation provided that the mutation } \\
\text { is known }\end{array}$ & Referral from different IVF centres. \\
\hline $\begin{array}{l}\text { Established } \\
\text { IVF unit }\end{array}$ & 1985 & 1986 & 2001 \\
\hline $\begin{array}{l}\text { PGD (FISH) } \\
\text { PGD -single gene } \\
\text { PGS-microarray CGH }\end{array}$ & $\begin{array}{l}2000 \\
2004 \\
-\end{array}$ & $\begin{array}{l}2002 \\
2005 \\
-\end{array}$ & $\begin{array}{l}2005 \\
2008\end{array}$ \\
\hline Number of annual IVF cycles & 1200 & $1000-1200$ & 1500 \\
\hline Number of annual PGD/PGS & $60-120$ & 100 & 220 \\
\hline
\end{tabular}

Table1: Summary of PGD centres in Saudi Arabia.

\section{PGD to Identify HLA savior siblings}

PGD for HLA tissue typing involves the use of PGD to select embryos that are free from a familial genetic disease and are a tissue match for an existing sibling who carries a genetic disease and needs a hematopoietic stem cell transplant [4,7]. This extended PGD indication is controversial [67]. The ethical debate focuses on the welfare of the donor child and whether the parents will love and value the child in his own right or only as a transplant source $[7,59,68]$. However, this issue must be balanced against the interests of the affected sibling [67]. If a stem cell transplant were unsuccessful, would the parents unconsciously blame the donor child? What would life be like for a child conceived to produce stem cells? These issues remain unclear. However, there is no evidence that the parents in this situation would love or value the donor less than any other child [59], and there are significant benefits for the sibling and the parents.

There is no fatwa regarding the use of PGD to select savior siblings. However, from an Islamic perspective, this process may be allowed because it may be beneficial for the affected child and the entire family, provided that they are well counseled. The couple must also agree to undergo an embryo transfer with an unaffected embryo even if it is non-matched. In some cases, they may be allowed to freeze any no matched unaffected embryos for possible future use.

\section{PGD for Late-onset Disorders and CancerPredisposition}

PGD for dominant, midlife-onset, untreatable disorders, such as Alzheimer's and Huntington diseases, is morally justified [59]. The use of PGD to screen for hereditary breast/ovarian cancer (HBOC) was approved in the UK by the HFEA [69]. However, its use for such indications continues to be controversial [70].

The argument in favor of PGD is that although mutations in BRCA1 and BRCA- 2 or ovarian cancer-linked genes are not $100 \%$ penetrant, the lifetime risk is still very high, between $50-80 \%$ for breast cancer and $20-50 \%$ for ovarian cancer [59]. The results of the long-term follow up of bilateral mastectomy patients remain to be established [71], and this surgery may have major effects on a woman's quality of life. However, PGD is costly and has a limited chance of success. Furthermore, the long-term outcomes are unknown, and there is a lack of clear guidance for embryo selection when there is a conflict between reproductive success and the genetic screening for disorders that do not profoundly affect the embryo or the resulting child [70].

Some believe that extending the indications for PGD is a "slippery slope", through which progressively less serious defects will be prevented by PGD, leading to the eventual selection of "designer babies". However, this argument can be addressed through adequate regulations.

\section{History of PGD and PND in Saudi Arabia}

The first private IVF practice in Saudi Arabia was founded in 1985. Currently, there are thirty IVF units in Saudi Arabia, nine of which are governmental, and PGD is practiced in three centers (one governmental and two private).

PGD was first practiced in 2000 in the founding IVF unit in Jeddah using FISH for sex selection and the detection of seven aneuploidies (two probes followed by five probes) and eight chromosomal translocations. Within two years, the governmental center in Riyadh (the capital) initiated a similar PGD program. PGD for monogenic disorders was added in 2004 in Jeddah and in 2005 in Riyadh. The third center in Al-Khubar began to offer PGD using FISH and screening for monogenic disorders in 2005. Since 2008, Al-Khubar centre have established PGS using array CGH in clinical practice, with promising initial results [72]. The number of IVF cycles conducted annually ranges from 1200 to 1500 in the PGD centers, and the number of PGD/ PGS cycles conducted annually ranges from 100 to 250 (Table 1).

PND is practiced sporadically in Saudi Arabia. There is no national program to screen for fetal anomalies due to the potential need for TOP. There is not yet consensus on which fetal anomalies are acceptable indications for TOP prior to 120 days. However, some diseases, such as thalassemia, sickle cell disease or Down syndrome, are not indications for TOP and cannot be prevented through PND.

\section{Conclusions}

Shari'a law recognizes the benefits of PGD in preventing inherited diseases, and it is considered an ethically superior approach to PND with respect to patient autonomy. Because of the balance of risk to the mother, most scholars agree that social sexing is not a sufficient justification for PGD. Both IVF and PGD are currently legal in Saudi, and staff and consumer evaluations are needed at this stage. (Sultan et al., in preparation)

\section{References}

1. Handyside AH, Kontogianni EH, Hardy K, Winston RM (1990) Pregnancies from biopsied human preimplantation embryos sexed by $\mathrm{Y}$-specific DNA amplification. Nature 344: 768-770.

2. Rechitsky S, Verlinsky O, Chistokina A, Sharapova T, Ozen S, et al. (2002) Preimplantation genetic diagnosis for cancer predisposition. Reprod Biomed Online 5: 148-155 
Citation: Sultan HA, Harper JC (2012) Legalization and Islamic Bioethical Perspectives on Prenatal Diagnosis and Advanced Uses of Preimplantation Genetic Diagnosis in Saudi Arabia. J Clinic Res Bioeth S1:003. doi:10.4172/2155-9627.S1-003

3. Verlinsky Y, Rechitsky S, Verlinsky O, Masciangelo C, Lederer K et al. (2002) Preimplantation diagnosis for early-onset Alzheimer disease caused by V717L mutation. JAMA 287: 1018-1021.

4. Verlinsky Y, Rechitsky S, Sharapova T, Morris R, Taranissi M et al. (2004) Preimplantation HLA testing. JAMA 291: 2079-2085.

5. Rechitsky S, Kuliev A, Tur-Kaspa I, Morris R, Verlinsky Y (2004) Preimplantation genetic diagnosis with HLA matching. Reprod Biomed Online 9: 210-221.

6. Kuliev A, Rechitsky S, Tur-Kaspa I, Verlinsky Y (2005) Preimplantation genetics: Improving access to stem cell therapy. Ann N Y Acad Sci 1054: 223-227.

7. Liu CK (2007) 'Saviour siblings'? The distinction between PGD with HLA tissue typing and preimplantation HLA tissue typing. J Bioeth Inq 4: 65-70.

8. Serour GI (2005) Religious perspectives of ethical issues in ART 1. Islamic perspectives of ethical issues in ART. Middle East Fertility Society Journal 10 : 185-190.

9. Unknown author (1992) Basic law of government. Kingdom of Saudi Arabia Chapter 2, article 8.

10. Eskandarani HA (2009) Pre-implantation genetic diagnosis in the Gulf Cooperative Council countries: utilization and ethical attitudes. Hum Reprod Genet Ethics 15: 68-74

11. Code of practice for all IVF, embryology, and infertility unites 436 in the Kingdom of Saudi Arabia, (2006a) Ministry of Health. (In Arabic); Chapter1: article3.

12. Code of practice for all IVF, embryology, and infertility unites in the Kingdom of Saudi Arabia, (2006b) Ministry of Health. (In Arabic); Chapter1: articleM9/L9.

13. Code of practice for all IVF, embryology, and infertility unites in the Kingdom of Saudi Arabia, (2006c) Ministry of Health. (In Arabic); Chapter1: article 13.

14. Code of practice for all IVF, embryology, and infertility unites in the Kingdom of Saudi Arabia, (2006d) Ministry of Health. (In Arabic); Chapter1: article 14.

15. Code of practice for all IVF, embryology, and infertility unites in the Kingdom of Saudi Arabia, (2006e) Ministry of Health. (In Arabic); Chapter 1: article 18.

16. Code of practice for all IVF, embryology, and infertility unites in the Kingdom of Saudi Arabia, (2006f) Ministry of Health. (In Arabic); Chapter 4: article 28.

17. Daar AS, al Khitamy AB (2001) Bioethics for clinicians: 21. Islamic bioethics CMAJ 164: 60-63.

18. Ajlouni KMS (2004) Cloning between Science and Religion (available in Arabic) Ajial Press, Amman, Jordan.

19. Al Othiamian MS (2006) Fundamentals of Islamic Jurisprudence "Isoul Alfagih" (available in Arabic) Al-Jawzi Press, Damam, KSA

20. Al Aqeel $\mathrm{Al}$ (2007) Islamic ethical framework for research into and prevention of genetic diseases. Nat Genet 39: 1293-1298.

21. Atighetchi D (2007) Islamic bioethics: Problems and perspectives. International library of ethics, law, and the new medicine, Springer, Netherland 13-28.

22. World Health Organisation Report (2003) Review of ethical issues in medical genetics: Report of Consultants to WHO. Professors Wertz DC, Fletcher JC. Berg Geneva, World Health Organisation, Human Genetics programme (WHO/ HGN/ETH/004).

23. Jarmulowicz M (2004) Dilemmas in Preimplantation genetic diagnosis. Catho Med Q

24. IFA fatwa on IVF (1986) Resolutions and recommendations of the council of Islamic Figh Academy 11-16 October 1986. Resolutions number 13-25 (In Arabic)-Jeddah.

25. Younis H (2008) Islam and bioethics. Obstetrics \& Gynaecology magazine, ethics and religion section 10: 24-26.

26. Modell B, Darr A (2002) Science and society: genetic counselling and customary consanguineous marriage. Nat Rev Genet 3: 225-229.

27. Teebi AS, Farag TI (1997) Genetic disorders among Arab populations. New York: Oxford University press. Oxford monographs on medical genetics.

28. Teebi AS, El-Shanti H (2006) Consanguinity: implications for practice, research, and policy. Lancet 367: 970-971.

29. Al-Gazali L, Hamamy H, Al-Arrayad S (2006) Genetic disorders in the Arab world. BMJ 333: 831-834.
30. Bayoumi R, Yardumian A (2006) Genetic disease in the Arab world. BMJ 333: 819

31. el-Hazmi MA, al-Swailem AR, Warsy AS, al-Swailem AM, Sulaimani R, et al (1995) Consanguinity among the Saudi Arabia population. J Med Genet 32 623-626.

32. el-Hazmi M, Warsy A (1996) Genetic disorders among Arab populations. Saud Medical Journal 17: 108-123.

33. al-Husain M, al-Bunyan M (1997) Consanguineous marriages in a Saud population and the effect of inbreeding on prenatal and postnatal mortality. Ann Trop Paediatr 17: 155-160.

34. El-Mouzan MI, Al-Salloum AA, Al-Herbish AS, Qurachi MM, Al-Omar AA (2007) Regional variations in the prevalence of consanguinity in Saudi Arabia. Saud Med J 28: 1881-1884.

35. NDR (2007) Central Department of Statistics \& Information. Kingdome of Saud Arabia.

36. Al-Odaib AN, Abu-Amero KK, Ozand PT, Al-Hellani AM (2003) A new era for preventive genetic programs in the Arabian Peninsula. Saudi Med J 24: 11681175.

37. Becker SM, Al Halees Z, Molina C, Paterson RM (2001) Consanguinity and Congenital Heart Disease in Saudi Arabia. Am J Med Genet 99: 8-13.

38. El Mouzan MI, AI Salloum AA, Al Herbish AS, Qurachi MM, Al Omar AA (2008) Consanguinity and major genetic disorders in Saudi children: a communitybased cross-sectional study. Ann Saudi Med 28: 169-173.

39. Weatherall D (1998) some aspects of the haemoglobinopathies of particular relevance to Saudi Arabia and other parts of the Middle East. Saudi Med J 9 . 107-115.

40. Al Aqeel Al (2005) Ethical guidelines in genetics and genomics: An Islamic perspective. Saudi Med J 26: 1862-1870.

41. Al-Suliman A (2006) Prevalence of beta-thalassaemia trait in premarital screening in Al-Hassa, Saudi Arabia. Ann Saudi Med 26: 14-16.

42. el-Hazmi MA, Warsy AS (1999) The pattern for common anaemia among Saudi children. J Trop Pediatr 45: 221-225.

43. Murshid WR (2000) Spina bifida in Saudi Arabia: is consanguinity among the parents a risk factor? Pediatr Neurosurg 32: 10-12.

44. Alsulaiman A, Hewison $\mathrm{J}$ (2006) Attitudes to prenatal and preimplantation diagnosis in Saudi parents at genetic risk. Prenat Diagn 26: 1010-1014.

45. Alhamdan NA, Almazrou YY, Alswaidi FM, Choudhry AJ (2007) Premarital screening for thalaessmia and sickle cell diseases in Saudi Arabia. Genet Med 9: 372-377.

46. Al Sulaiman A, Saeedi M, Al Suliman A, Owaidah T (2010) Postmarital followup survey on high risk patients subjected to premarital screening program in Saudi Arabia. Prenat Diagn 30: 478-481.

47. Islamic Figh Academy (Jeddah) (2000) Resolutions and recommendations of the council of Islamic Figh Academy 1985-2000, Jeddah (Saudi Arabia). (1st edn), Islamic Development Bank.

48. Albar MA (2002) Ethical considerations in the prevention and management of genetic disorders with special emphasis on religious considerations. Saudi Med J 23: 627-632.

49. Islamic Figh Academy India (IFAI) (2006) Prenatal diagnosis and termination of pregnancy after 120 days and pre implantation genetic diagnosis; 15th 9 session held in India (11-13 March 2006); (in Arabic).

50. CSS fatwa (1995) Saudi Council of Senior Scholar fatwa number (17576) date 19-01-1416 H. Termination of pregnancy before 40 days, (in Arabic).

51. TOP rules and regulations act from $\mathrm{MOH}$ (2002) Saudi Ministry of Health Act number 1069/25H/47C date 12-04-1423H (2002). Roles and regulations for termination of pregnancy in Saudi Hospitals and clinic (in Arabic).

52. Akosy S (1998) Can Islamic texts help to resolve the problem of the moral status of the prenate? Eubios $\mathrm{J}$ Asian Int Bioeth 8: 76-79.

53. Sachedina A (2009) Terminating early life: Islamic biomedical ethics: principles and application. (1st edn), Oxford university press, Inc. New York. 125-144.

54. Harper JC, Handyside A (1994) The current status of preimplantation diagnosis. Curr Obstet Gynaecol 4: 143-149. 
Citation: Sultan HA, Harper JC (2012) Legalization and Islamic Bioethical Perspectives on Prenatal Diagnosis and Advanced Uses of Preimplantation Genetic Diagnosis in Saudi Arabia. J Clinic Res Bioeth S1:003. doi:10.4172/2155-9627.S1-003

55. Harper JC Harton G (2010) The use of array in preimplantation genetic diagnosis and screening. Fertil Steril 94: 1173-1177.

56. Serour GI, Dickens BM (2001) Assisted reproduction developments in the Islamic world. Int J Gynaecol Obstet 74: 187-193.

57. Serour GI (2008) Islamic perspectives in human reproduction. Reprod Biomed Online 3: $34-38$

58. Ogilvie C, Scriven P (2009) Preimplantation genetic diagnosis for sex-linked diseases and sex selection for non-medical reasons: Preimplantation genetic diagnosis. (2nd edn), Harper J.C. Cambridge University press. 230-236.

59. De Wert G (2009) Preimplantation genetic testing: normative reflections: Preimplantation genetic diagnosis. (2nd edn), Harper J.C. Cambridge University press. 259-273.

60. Goossens V, Harton G, Moutou C, Scriven PN, Traeger-Synodinos J, et al. (2008) ESHRE PGD Consortium data collection VIII: cycles from January to December 2005 with pregnancy follow up to October 2006. Hum Reprod 23: 2629- 2645.

61. Robertson J (2002) Sex selection: Final word from ASRM ethics committee on the use of PGD. Hastings Cent Rep 32: 6 .

62. Serour GI (2004) Transcultural issues in gender selection. International Congress Service 1266: 21-31.

63. Healy DL (2002) Reproductive medicine in the twenty-first century: Proceeding of the 17th World Congress on Fertility and Sterility, Melbourne: Australia (1st edn). The Parthenon Publishing group. 97-106.
64. IFA fatwa (2007) Sex selection for medical and non-medical indications and screening embryos to prevent diseases and discard abnormal embryos. Islamic Figh Academy - Organization of Islamic Conference (OIC) Jeddah. 19th 5 Annual meeting held in Mecca (3-8 November 2007). (In Arabic).

65. Albar M (2008) Sex selection. Islamic Figh Academy Journal 20: 159- 204 (in Arabic).

66. Hans Galjaard (2003) Report of the International Bioethical Committee (IBC) on Pre-implantation Genetic Diagnosis and Germ-line Intervention. United Nation Educational Scientific and Cultural Organisation (UNESCO). SHS582EST/02/ CIB-9/2(Rev.3) Paris, 24 April 2003. 1-18

67. Pennings G, de Wert G (2003) Evolving ethics in medically assisted reproduction. Hum Reprod Update 9: 397-404

68. Boyle RJ, Savulescu J (2001) Ethics of using preimplantation genetic diagnosis to select a stem cell donor for an existing person. BMJ 323: 1240-1243.

69. Human Fertilisation and Embryology Authority (HFEA), Authority Decision on the use of PGD for lower penetrance, later onset inherited conditions. London: HFEA.

70. Noble R, Bahadur G, Iqbal M, Sanyal A (2008) Pandora's Box: ethics of PGD for inherited risk of late onset disorders. Reprod Biomed Online 3: 55-60.

71. Meijers-Heijboer $H$, van Geel B, van Putten WL, Henzen-Logmans SC Seynaeve C, et al. (2001) Breast cancer after prophylactic bilateral mastectomy in women with BRCA1 or BRCA2 mutation. N Engl J Med 345: 159-164.

72. Hellani A, Abu-Amero K, Azouri J, El-Akoum S (2008) Successfu pregnancies after application of array-comparative genomic hybridization in PGS601aneuploidy screening. Reprod Biomed Online 17: 841-847.
This article was originally published in a special issue, Ethics: Reproductive Technologies handled by Editor(s). Dr. Stephen Napier, Villanova University, USA 